\title{
Alterations of Hypoxia-Inducible Factor-1 Alpha in the Hippocampus of Mice Acutely and Repeatedly Exposed to Hypoxia
}

\author{
Guo Shao ${ }^{a-c}$ Cui-Ying Gao ${ }^{a}$ Guo-Wei Luª \\ ${ }^{a}$ Department of Neurobiology and ${ }^{b}$ Institution for Hypoxia Medicine, Capital University of Medical Sciences, \\ Beijing, and ${ }^{\mathrm{c}}$ Medical College of Jishou University, Jishou, China
}

\section{Key Words}

Hypoxic preconditioning - Hippocampus, hypoxiainducible factor- 1 alpha alterations $\cdot$ Hypoxia-inducible factor-1 alpha, hippocampus

\begin{abstract}
This work aims at investigating the effects of hypoxic preconditioning on hypoxia-inducible factor-1 alpha (HIF-1 $\alpha$ ) expression in the hippocampus of mice during acute and repeated hypoxic exposures. The mice were randomly divided into three groups and exposed, respectively, to hypoxia for 4 runs (group H4), 1 run (group $\mathrm{H} 1$ ), and 0 run (group H0). Reverse transcription-polymerase chain reaction (RT-PCR), Western blot, electrophoretic mobility shift assay (EMSA), and chromatin immunoprecipitation were used to examine the HIF- $1 \alpha$ responses in the mouse hippocampus following exposure to hypoxia. The tolerance of mice to hypoxia increased significantly following acute and repetitive exposure to autoprogressive hypoxia. Total mRNA, total protein, and nuclear protein were extracted from the hippocampus for RT-PCR, Western blot, and EMSA, respectively. The HIF- $1 \alpha$ mRNA levels were found to be in-
\end{abstract}

Dr. G. Shao is now at the Department of Biochemistry, Medical School, Jiaxing University.

\section{KARGER}

Fax +4161306 1234 E-Mail karger@karger.ch www.karger.com
(C) 2005 S. Karger AG, Basel

$1424-862 X / 05 / 0145-0255 \$ 22.00 / 0$

Accessible online at: www.karger.com/nsg creased in group $\mathrm{H} 1$ and decreased in group $\mathrm{H} 4$. The HIF-1 $\alpha$ protein levels and HIF-1 DNA-binding activities were increased in group $\mathrm{H} 1$ and markedly increased in group H4. One of the HIF-1 target genes, vascular endothelial growth factor, increased in group H4. HIF-1 activation is thought to be involved in the protection of the brain of hypoxic preconditioned mice.

Copyright $(2005$ S. Karger AG, Basel

\section{Introduction}

Over the last decade, a lot of reports have demonstrated that in rodents a phenomenon called hypoxic preconditioning can be induced in the brain. Hypoxic preconditioning is defined as a period of sublethal hypoxia insult which can induce a protection from an otherwise lethal insult. Our previous work [1] showed that the tolerance to hypoxia in adult mice was significantly increased by acute and repetitive exposure to autoprogressive hypoxia. The quantities or activities of some chemical materials and gas/energy metabolism in the brain were found to be changed during the preconditioning in our model $[2,3]$.

The mechanism of hypoxic preconditioning is still unclear, but is believed to trigger endogenous cellular adaptation. The complex cellular signaling cascades and downstream genes and protein regulatory processes were suggested to be factors involved in the preconditioning [4]. 
As a key molecule in hypoxia, hypoxia-inducible factor-1 (HIF-1) regulates the activities of genes that have in common one or more binding sites for HIF-1. HIF-1 is a member of the basic helix-loop-helix family and consists of an oxygen-regulated alpha subunit and a constitutively expressed beta subunit [5]. Under normoxic conditions, HIF- $1 \alpha$ is hydroxylated by the HIF prolyl hydroxylase family $[6,7]$, and the hydroxylation reaction requires molecular oxygen and Fe(II) [8, 9]. The von Hippel-Lindau tumor suppressor protein, a ubiquitin protein ligase, recognizes HIF- $1 \alpha$ that has been modified at the two proline residues and binds to a region of HIF- $1 \alpha$ named oxygendependent degradation domain [10]. Thus HIF- $1 \alpha$ is damaged through the ubiquitin path. Under hypoxic conditions, HIF- $1 \alpha$ escapes the damage and dimerizes with HIF-1 $\beta$ and binds to the hypoxic response element of many target genes, leading to the transcriptional activation of several dozen genes such as erythropoietin (EPO), vascular endothelial growth factor (VEGF), and so on [11]. EPO and VEGF have been proved to have the role of neuroprotective factors $[12,13]$.

The purpose of this study was to investigate the change of HIF-1 expression, when mice were exposed to hypoxia acutely and repetitively. In addition, the induction of VEGF, one of the HIF-1 target genes, was also measured during the preconditioning.

\section{Materials and Methods}

\section{Animal Model}

Male adult BALB/C mice (weighing 16.0-22.0 g) were randomly separated into three groups: blank control group with no exposure to hypoxia $(\mathrm{H} 0)$, hypoxia control group exposed to hypoxia once (H1), and hypoxia preconditioning group exposed to hypoxia for four runs (H4). The procedure of the hypoxic experiment was performed as previously described [2]. Briefly, the animal was placed into a $125-\mathrm{ml}$ jar with fresh air, and the jar was sealed with a rubber plug. The animal was removed from the jar as soon as the first gasping breath appeared and was switched to another fresh-air-containing jar of similar volume. This procedure was performed once (group H1) or repeated four times (group H4). The appearance of the first gasping was regarded as the tolerance limit in each trial. The time period between the beginning of airtightness and the appearance of the first gasping was termed 'tolerance time' for each run.

\section{RNA Isolation and Semiquantitative Reverse Transcription-}

\section{Polymerase Chain Reaction (RT-PCR) Analysis}

Total RNA was prepared from mouse hippocampus using the Rneasy minikit (Qiagen, Valencia, Calif., USA). Total RNA $(1 \mu \mathrm{g})$ was reverse transcribed with Superscript II reverse transcriptase (Invitrogen, Carlsbad, Calif., USA). One microliter of the resulting cDNAs was subjected to amplification in a total volume of $20 \mu \mathrm{l}$ containing $10 \times$ buffer, $1.5 \mathrm{mmol} / 1 \mathrm{MgCl}_{2}, 0.2 \mathrm{mmol} / \mathrm{l}$ of each dNTP, 1 U Taq polymerase (Takara, Otsu, Japan), and a pair of specific primers $(0.2 \mu \mathrm{mol} / 1 \mathrm{each})$. Primers for HIF- $1 \alpha$ and glyceraldehyde-3-phosphate dehydrogenase (GAPDH) were designed using Primer Premier 5.0 software, and both sequences were obtained from GenBank: GAPDH forward primer: 5'-CCCTTCATTGACCTCAAC-3', reverse primer: 5'-TTCACACCCATCACAAAC-3'; HIF- $1 \alpha$ forward primer: 5'-TATAAACCTGGCAATGTCTCC-3', reverse primer: 5'-GATGCCTTAGCAGTGGTCGT-3'. The PCR temperature for HIF- $1 \alpha$ was as follows: cycles at $92^{\circ} \mathrm{C}$ for $30 \mathrm{~s}$, at $53^{\circ} \mathrm{C}$ for $30 \mathrm{~s}$, and at $72^{\circ} \mathrm{C}$ for $60 \mathrm{~s}$, total 29 cycles, followed by a final extension period at $72^{\circ} \mathrm{C}$ for $5 \mathrm{~min}$. The PCR temperature for GAPDH was: cycles at $92^{\circ} \mathrm{C}$ for $40 \mathrm{~s}$, at $50^{\circ} \mathrm{C}$ for $40 \mathrm{~s}$, and at $72^{\circ} \mathrm{C}$ for $45 \mathrm{~s}$, total 20 cycles, followed by a final extension period at $72^{\circ} \mathrm{C}$ for $5 \mathrm{~min}$. PCR products $(9 \mu \mathrm{l})$ were separated by $1.0 \%$ agarose gel electrophoresis and stained with ethidium bromide. The RT-PCR products were 672 bp for HIF-1 $\alpha$ and $301 \mathrm{bp}$ for GAPDH.

\section{Western Blot Analysis}

Total proteins from mouse hippocampus were extracted according to a previously described protocol [14]. The protein concentrations were determined using the bicinchoninic acid method. Total cell lysate of mouse hippocampus $(80 \mathrm{~g})$ was separated by SDS $(8 \%) / P A G E(12 \%)$ at $30 \mathrm{~mA}$ for $2.5 \mathrm{~h}$ and then blotted onto a nitrocellulose membrane. The membrane was then incubated for $1 \mathrm{~h}$ in blocking buffer (Tris-buffered saline containing 10\% skimmedmilk powder) at room temperature. Next, the membrane was incubated for $16 \mathrm{~h}$ at $4^{\circ} \mathrm{C}$ with the primary antibodies. Then, the membrane was incubated with secondary antibodies for $1 \mathrm{~h}$ at room temperature. After each incubation, the membrane was washed three times thoroughly with Tris-buffered saline containing $0.05 \%$ Tween 20. Protein signals were detected by an electrochemiluminescence detection system (Pierce Biotechnology, Rockford, Ill., USA), in which the membrane was exposed to the detection solution for $5 \mathrm{~min}$.

\section{Preparation of Nuclear Protein Extracts}

The whole hippocampus was broken into single cells with cold phosphate-buffered saline after hypoxia exposure or not. The cell pellet was centrifuged, and the resulting pellet was lysed in lysis buffer A $\left(10 \mathrm{mmol} / 1 \mathrm{HEPES}, 10 \mathrm{mmol} / \mathrm{K} \mathrm{KCl}, 1.5 \mathrm{mmol} / 1 \mathrm{MgCl}_{2}\right.$, $1 \mathrm{mmol} / \mathrm{l}$ EDTA, $1 \mathrm{mmol} / 1$ dithiothreitol, $1 \mathrm{mmol} / 1$ phenylmethylsulfonyl fluoride (PMSF), and $1 \mu \mathrm{g} / \mathrm{ml}$ protease inhibitors in distilled water). Ten minutes later, the cells were homogenized on ice and investigated by microscope using trypan blue. The samples were centrifuged for $15 \mathrm{~min}$ at $3,000 \mathrm{rpm}$ at $4^{\circ} \mathrm{C}$. The supernatants (cytosolic extracts) were discarded, and the resulting pellet (nucleus) was resuspended in buffer B (25\% glycerol, $20 \mathrm{mmol} / 1$ HEPES, $20 \mathrm{mmol} / 1 \mathrm{KCl}, 1.5 \mathrm{mmol} / 1 \mathrm{MgCl}_{2}, 1 \mathrm{mmol} / 1 \mathrm{EDTA}, 1 \mathrm{mmol} / 1 \mathrm{di}-$ thiothreitol, $1 \mathrm{mmol} / 1 \mathrm{PMSF}$, and $1 \mu \mathrm{g} / \mathrm{ml}$ protease inhibitors in distilled water), then high-salt buffer $\mathrm{C}$ (20 mmol/1 HEPES, $1 \mathrm{mmol} / 1$ EDTA, $1.5 \mathrm{mmol} / 1 \mathrm{MgCl}_{2}, 25 \%$ glycerol, $1.2 \mathrm{~mol} / 1 \mathrm{KCl}$, $1 \mathrm{mmol} / 1$ dithiothreitol, $1 \mathrm{mmol} / 1 \mathrm{PMSF}$, and $1 \mu \mathrm{g} / \mathrm{ml}$ protease inhibitors in distilled water) was added dropwise while stirring gently. The suspension was mixed vigorously with tips and incubated on ice for $30 \mathrm{~min}$. The samples were centrifuged for $10 \mathrm{~min}$ at $14,000 \mathrm{rpm}$ at $4^{\circ} \mathrm{C}$, and the supernatants (nuclear extracts) were kept at $-80^{\circ} \mathrm{C}$. 
Electrophoretic Mobility Shift Assay (EMSA)

EMSA was performed according to the method of Semenza and Wang [15]. The EPO gene-derived sense oligonucleotide sequence GCCCTACGTGCTGCCTCGCATGGC contains a HIF-1-binding site. Sense and antisense oligonucleotides were annealed in annealing buffer and then were labeled with $\left[\gamma-\mathrm{p}^{32}\right]$ ATP by T4 polynucleotide kinase (Takara). Unincorporated nucleotides were removed by using the QIAquick nucleotide removal kit (Qiagen). Nuclear protein was added to binding buffer (HEPES $60 \mathrm{~m} M$, EDTA $5 \mathrm{~m} M, \mathrm{KCl} 300 M, 10 \%$ glycerol, dithiothreitol $5 \mathrm{~m} M$, Tris$\mathrm{HCl} 20 \mathrm{mM}$ ) containing $1.5 \mu \mathrm{g}$ poly(dI-dC) (Sigma, St. Louis, Mo., USA), with or without antiboby. Then the mixture was incubated on ice for $30 \mathrm{~min}$ before addition of $1 \times 10^{4} \mathrm{cpm}$ of oligonucleotide probe in a total volume of a $20-\mu$ l solution for 1 additional hour. Samples were run on $4 \%$ nondenaturing polyacrylamide gels at 200-250 V for 2-3 h in 0.5 $\times$ TBE buffer (Tris-borate-EDTA) at $4{ }^{\circ} \mathrm{C}$. Afterwards, the gels were dried and autoradiographed.

\section{Chromatin Immunoprecipitation (ChIP) Assay and Real-Time} PCR

The hippocampus of mice was prepared into single-cell supernatants on ice using phosphate-buffered saline. ChIPs were performed following the Upstate Biotechnology (Waltham, Mass., USA) assay kit protocol. Briefly, formaldehyde was added to the cold phosphate-buffered saline at a final concentration of $3 \%$, then the solution was incubated at $37^{\circ} \mathrm{C}$ for $10 \mathrm{~min}$. Cross-linked DNA was sheared to $200-1,000 \mathrm{bp}$ by sonication. A portion of cell supernatant was kept as the input material, and the remaining solution was immunoprecipitated using an anti-HIF-1 $\alpha$ antibody (Santa Cruz Biotechnology, Santa Cruz, Calif., USA) or an unrelated antibody (IgG) as negative control. The DNA was reversed from the protein-DNA complex and used as template for PCR. The fragments of the housekeeping gene $\beta$-actin and EPO 3 '-terminal sequence including the HIF-1-binding site were amplified. The primers for PCR of mouse $\beta$-actin fragment and EPO 3 '-terminal sequence were as follows: $\beta$-actin forward primer: 5'-GAACGGTGAAGGCGACAG-3', $\beta$-actin reverse primer: 5'-TTGGGAGGGTGAGGGACT-3'; EPO 3' enhancer forward primer: 5'-GTCGCAAGGCATCAGA-3', EPO 3' enhancer reverse primer: 5'CTTGTCCTAGCGGGTT-3'. The products were 175 and $187 \mathrm{bp}$, respectively. The PCR condition for both primer sets was as follows: hot start at $95^{\circ} \mathrm{C}$ for $2 \mathrm{~min} ; 33$ cycles, each consisting of $92^{\circ} \mathrm{C}$ for $25 \mathrm{~s}, 52^{\circ} \mathrm{C}$ for $40 \mathrm{~s}$, and $72^{\circ} \mathrm{C}$ for $25 \mathrm{~s}$ and a final extension at $72^{\circ} \mathrm{C}$ for $5 \mathrm{~min}$. The PCR products were separated on $1 \%$ agarose gels and stained with ethidium bromide.

DNA obtained from ChIP was used as template, and the same EPO 3' enhancer HRE primer used in PCR was applied as primer in real-time PCR. The TaqMan probe was: 5'-CTTGAGGCCACAATACCTGC- $3^{\prime}$. Thermal cycling conditions were $94^{\circ} \mathrm{C}$ before 40 PCR cycles $\left(92^{\circ} \mathrm{C}, 30 \mathrm{~s} ; 52^{\circ} \mathrm{C}, 80 \mathrm{~s}\right)$.

\section{Quantification and Statistics}

The optical densities (OD) of bands of PCR products, Western blot, and EMSA were obtained through the Gel-Doc system and analyzed by Bandscan software. The data of RT-PCR are presented as relative abundance, and Western blots and EMSA are presented as OD. All data are expressed as mean values \pm SD. Statistical analysis was performed by means of ANOVA and Tukey test using SPSS 10.0 software. $\mathrm{p}<0.05$ was considered to be statistically significant.

Alterations of Hypoxia-Inducible Factor-1 Alpha in the Mouse Hippocampus

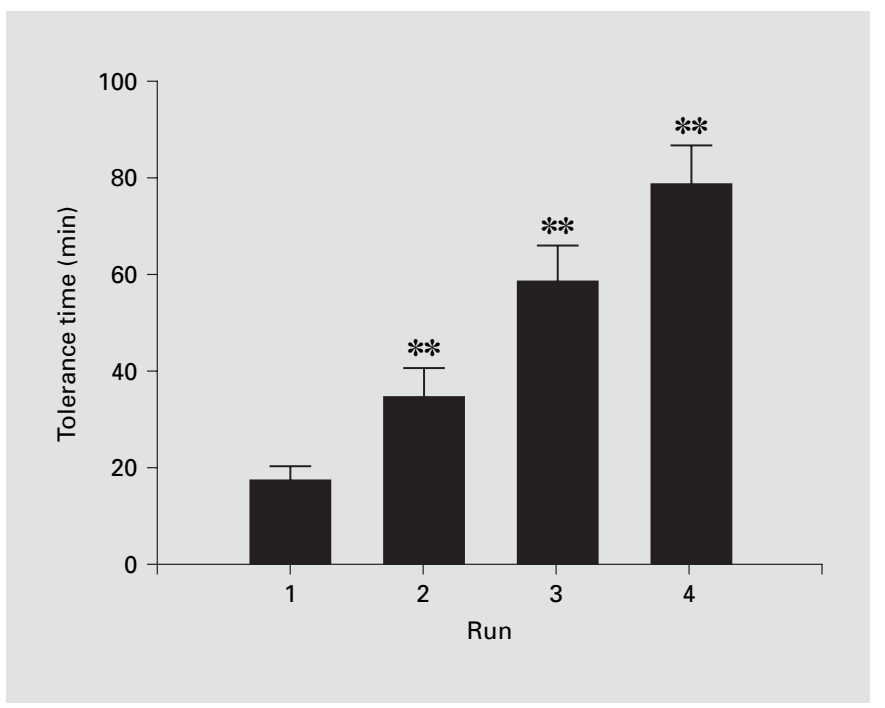

Fig. 1. Tolerance time in the different exposure runs $(n=30$; $* * \mathrm{p}<0.01$ as compared with the preceding runs).

\section{Results}

\section{Effects of Acute and Repeated Hypoxia on the}

Tolerance Time of Mice

The increment of tolerance to hypoxia in each run was approximately in an arithmetic progression. The tolerance time of each run lasted significantly longer and longer, as the exposure run increased. The average tolerance times of runs $1,2,3$, and 4 were $17.2 \pm 2.9,37.4 \pm 5.7$, $58.5 \pm 7.3$, and $78.7 \pm 7.9 \mathrm{~min}$, respectively (fig. 1), which was in accordance with our previous findings [1-3].

\section{Effects of Acute and Repeated Hypoxia on HIF-1 $\alpha$ $m R N A$}

The HIF- $1 \alpha$ mRNA was analyzed by RT-PCR immediately at the end of hypoxia exposures. The relative abundance value of HIF- $1 \alpha$ in each group of HIF- $1 \alpha$ mRNA was calculated by the OD ratio of HIF- $1 \alpha$ to GAPDH. The relative abundance values of group H1 $(5.67 \pm 1.79)$ were significantly higher than those of group $\mathrm{H} 0(2.41 \pm 0.56 ; \mathrm{p}<0.05)$. However, after repetitive hypoxia exposure, the HIF-1 $\alpha$ values recovered at mRNA level in group H4 (3.76 \pm 0.97$)$. A significant difference of the relative quantities of HIF- $1 \alpha$ between group $\mathrm{H} 1$ and group $\mathrm{H} 4$ was detected ( $<<0.05)$, and no difference between $\mathrm{H} 0$ and $\mathrm{H} 4$ groups was shown. The results of RT-PCR products of HIF- $1 \alpha$ and GAPDH are shown 


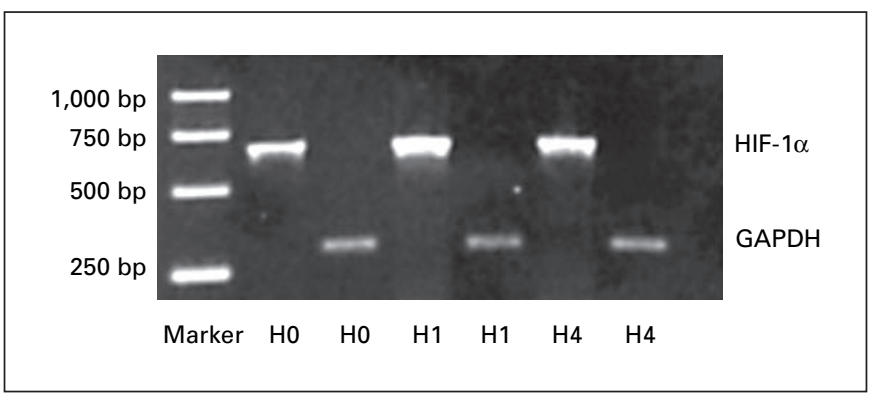

Fig. 2. Electrophoresis of HIF- $1 \alpha$ and GAPDH RT-PCR products in agarose gel.

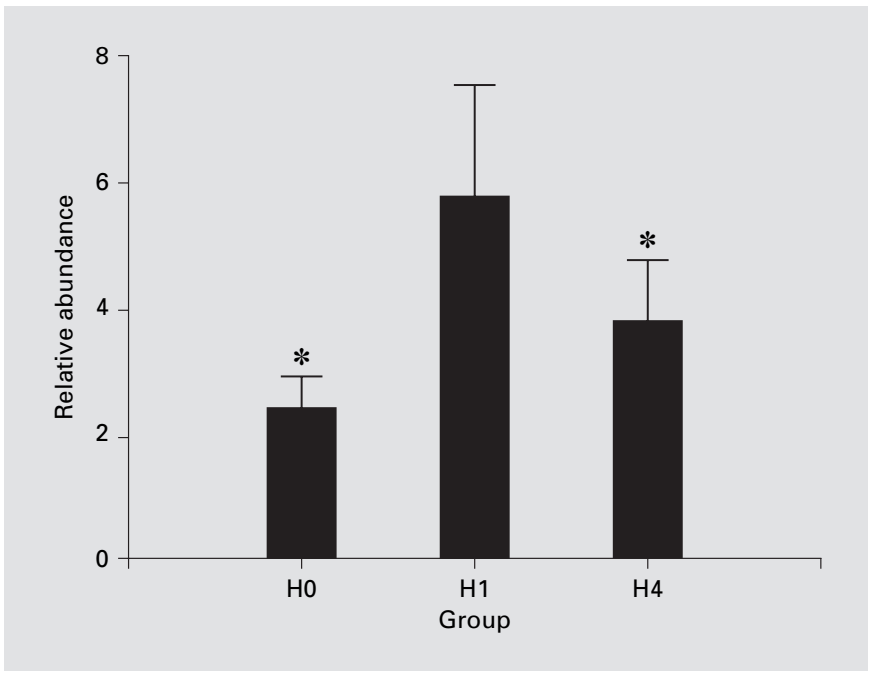

Fig. 3. Ratio of HIF- $1 \alpha$ mRNA to GAPDH mRNA in $\mathrm{H} 0, \mathrm{H} 1$, and H4 groups $\left(n=6 ;^{*} p<0.05\right.$ vs. group $\left.H 1\right)$.

in figure 2, and the relative abundance of HIF- $1 \alpha$ to GAPDH is shown in figure 3.

\section{Effects of Acute and Repeated Hypoxia on HIF-1 $\alpha$ \\ Protein}

HIF- $1 \alpha$ protein was detected in three groups by Western blot (fig. 4), using a rabbit polyclonal antibody (Santa Cruz Biotechnology). A faint band of about $120 \mathrm{kDa}$ was seen in group H0 (OD 1,577 \pm 366 ), while a more distinct band of HIF-1 $\alpha$ protein was seen at the corresponding location in groups $\mathrm{H} 1$ and $\mathrm{H} 4$. The HIF- $1 \alpha$ protein level was increased in both group H1 (OD 3,817 $\pm 1,723)$ and group H4 (OD 14,478 $\pm 7,199$ ). The HIF-1 $\alpha$ protein levels in group $\mathrm{H} 4$ were significantly higher than those seen

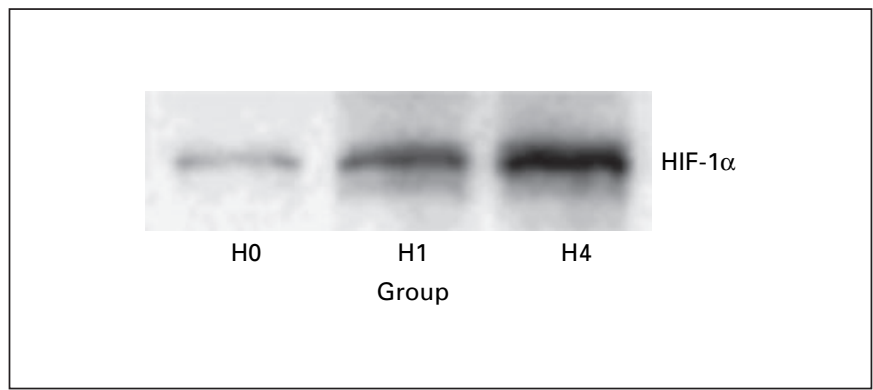

Fig. 4. Western blot analysis of HIF- $1 \alpha$ in the hippocampus of the mice in groups $\mathrm{H} 0, \mathrm{H} 1$, and $\mathrm{H} 4$.

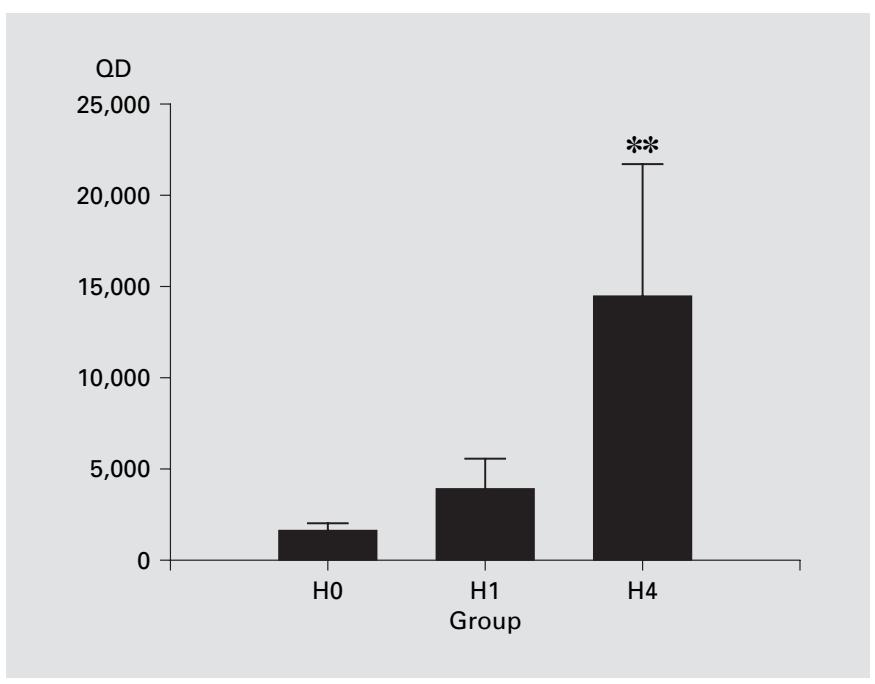

Fig. 5. Expression of HIF-1 $\alpha$ protein in mouse hippocampi $(n=6$; ** $\mathrm{p}<0.01$ vs. groups $\mathrm{H} 0$ and $\mathrm{H} 1$ ).

in groups $\mathrm{H} 0$ and $\mathrm{H} 1$ ( $\mathrm{p}<0.01$ vs. $\mathrm{H} 0$ and $\mathrm{H} 1, \mathrm{n}=6$; fig. 5). The increase of the protein level was parallel to the increase of the tolerance time.

\section{Effects of Acute and Repeated Hypoxia on the}

DNA-Binding Activities of HIF-1

The in vitro hippocampal DNA-binding activities were analyzed by EMSA (fig. 6). The DNA-binding activities of HIF-1 were constitutively expressed under normal conditions. A 20- to 28-fold increase was seen in group $\mathrm{H} 1$ (vs. group $\mathrm{H} 0$ ). The activity in group $\mathrm{H} 4$ was even higher than that in group H1 (1.2- to 1.8-fold). The in vivo hippocampal DNA-binding activities of HIF-1 were analyzed by ChIP (fig. 7). The DNA obtained by 


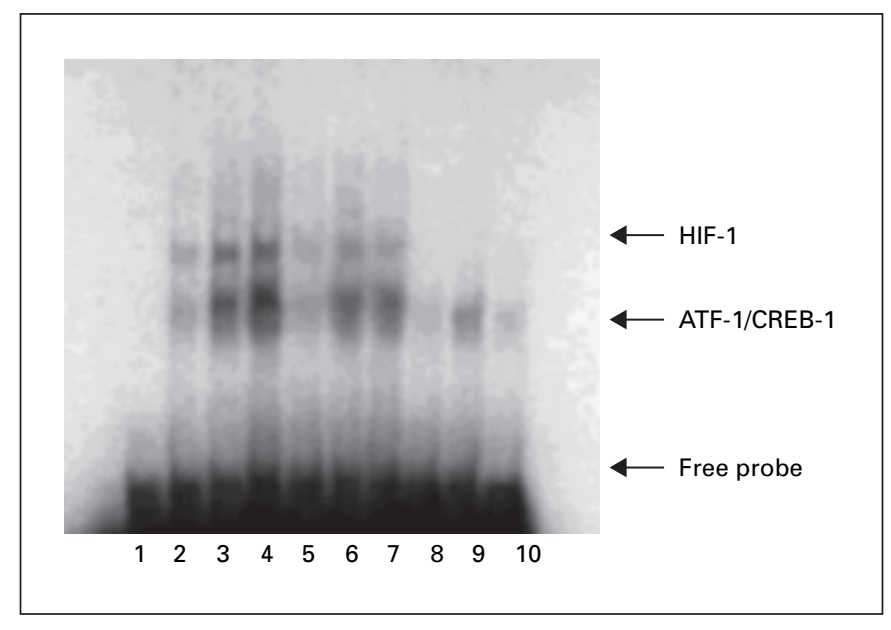

Fig. 6. DNA-binding activities of HIF-1 on the EPO hypoxia response element (CREB-1) in the different groups. Lane 1: protein free. EMSA using crude nuclear extract was prepared from group H0 (lanes 2, 5, 8), group H1 (lanes 3, 6, 9), and group H4 (lanes 4, $7,10)$. For supershift assays (lanes 5-7), binding reactions contained $2 \mu 1$ antiserum raised against HIF- $1 \alpha$ (ATF-1). For competition assays (lanes $8-10$ ), binding reactions included 100-fold excess of unlabeled oligonucleotides $(n=3)$.

ChIP was used as a template for RT-PCR and real-time PCR. The results of in vivo binding were similar to those of in vitro binding. The DNA-binding activities of HIF-1 could be detected in the three groups by RT-PCR. The $\mathrm{Ct}$ values were $31.51,30.65$, and 28.65 in groups $\mathrm{H} 0, \mathrm{H} 1$, and $\mathrm{H} 4$, respectively $(\mathrm{n}=6)$. Both in vitro and in vivo binding tests showed that the HIF-1 DNA-binding activities were increased in group $\mathrm{H} 1$ and markedly increased in group $\mathrm{H} 4$.

\section{Effects of Acute and Repeated Hypoxia on VEGF Protein}

VEGF protein was detected in the three groups by Western blot using a mouse monoclonal antibody (Santa Cruz Biotechnology). The $\beta$-actin protein was used as internal control. The relative abundance value of VEGF protein in each group was calculated by the OD ratio of VEGF protein to $\beta$-actin protein. As shown in figure 8, no significant difference was found between group $\mathrm{H} 0$ $(0.208 \pm 0.05)$ and group $\mathrm{H} 1(0.200 \pm 0.08)$, while there were marked changes in group $\mathrm{H} 4(0.387 \pm 0.08)$. The VEGF protein levels were increased almost twofold in group $\mathrm{H} 4$ ( $\mathrm{p}<0.01$ vs. groups $\mathrm{H} 0$ and $\mathrm{H} 1, \mathrm{n}=6$; fig. 9).

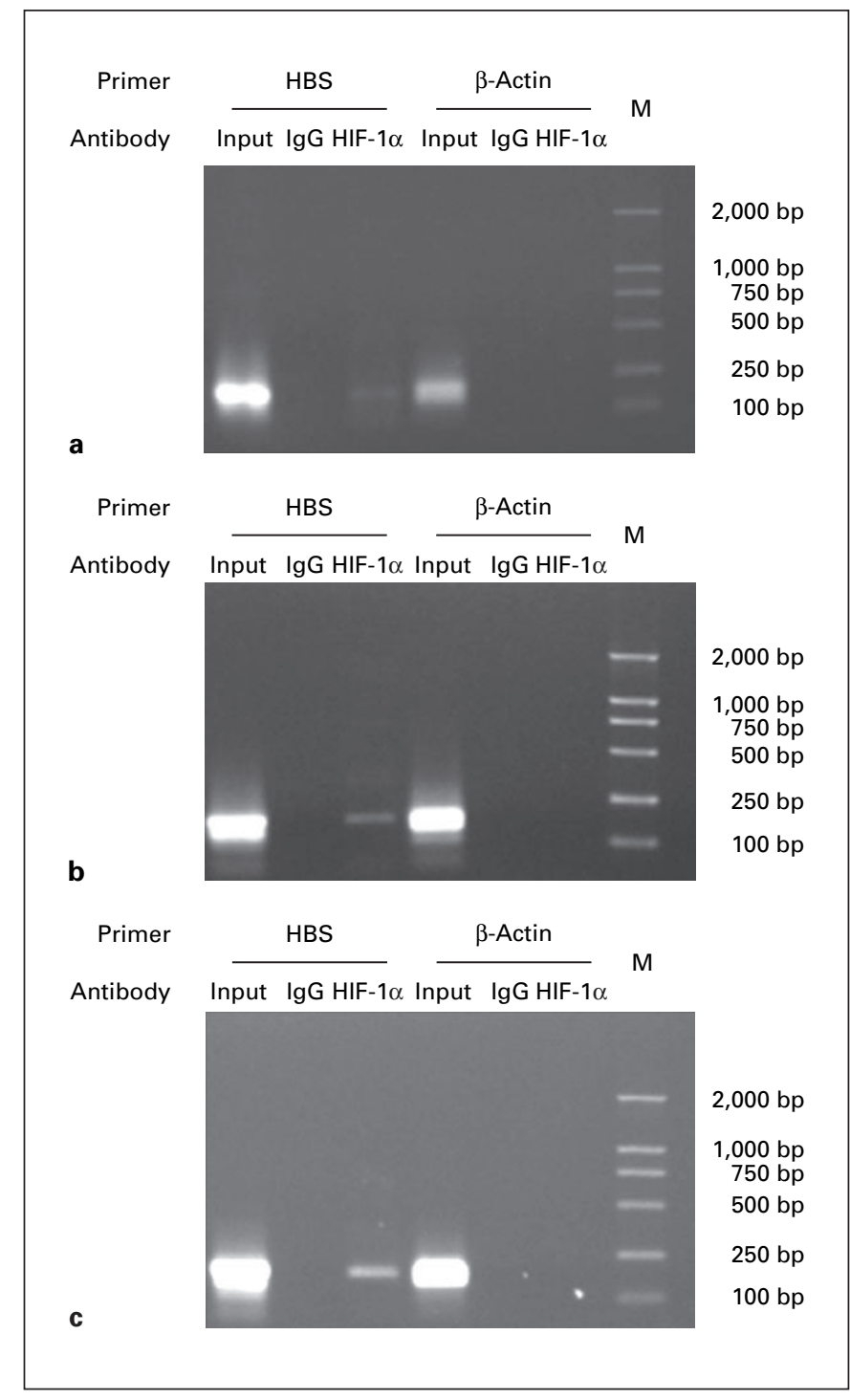

Fig. 7. Electrophoresis of ChIP PCR products in agarose gel. Samples from group $\mathrm{H} 0$ (a), group $\mathrm{H} 1$ (b), and group $\mathrm{H} 4$ (c). $\mathrm{M}=$ Marker; HBS = hypoxia binding site.

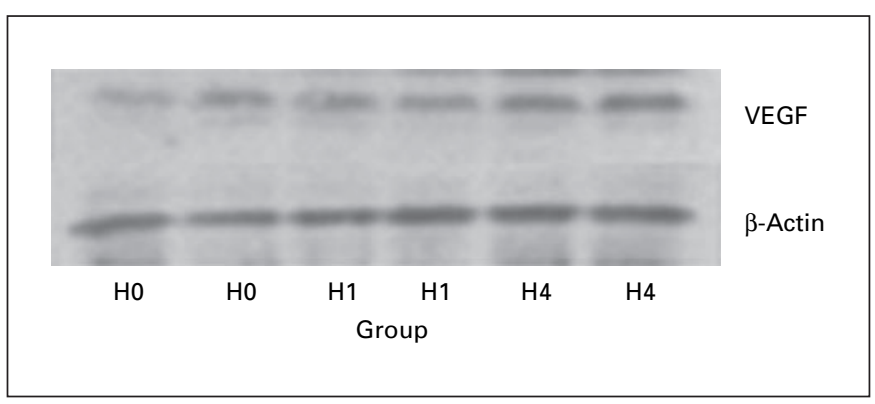

Fig. 8. Western blot analysis of VEGF and $\beta$-actin in the hippocampus of mice in groups $\mathrm{H} 0, \mathrm{H} 1$, and $\mathrm{H} 4$. 


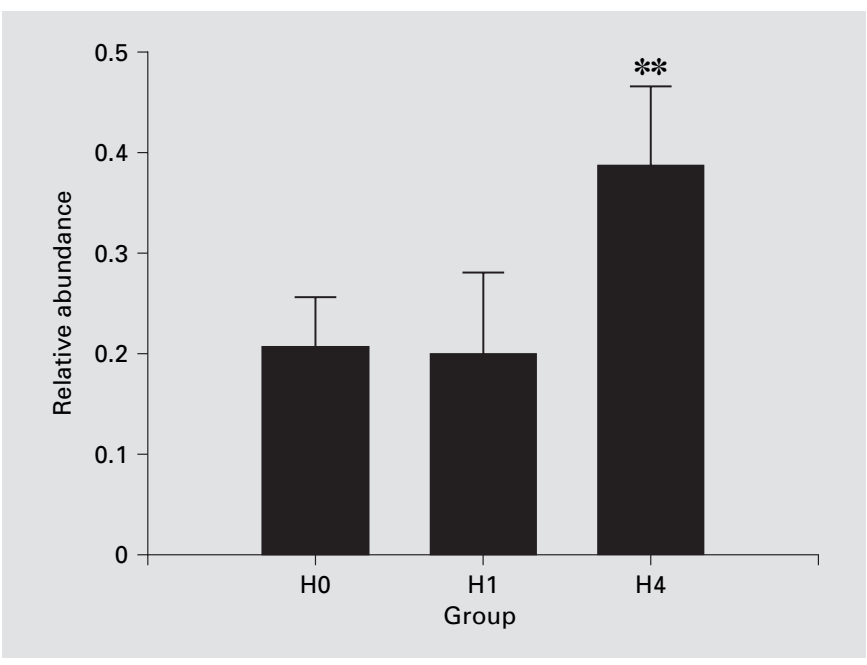

Fig. 9. Ratio of VEGF protein to $\beta$-actin protein in $\mathrm{H} 0, \mathrm{H} 1$, and $\mathrm{H} 4$ groups $\left(\mathrm{n}=6 ;{ }^{* *} \mathrm{p}<0.01\right.$ vs. groups $\mathrm{H} 0$ and $\left.\mathrm{H} 1\right)$.

\section{Discussion}

Acute and chronic preconditioning procedures are accepted as two mechanistically distinct kinds of protection afforded by hypoxia, and the mechanism of acute and chronic preconditioning is thought to be different [16]. However, acute and chronic preconditioning may have similar biochemical components [17]. Most of the researchers focus on the role of HIF-1 in chronic preconditioning in immature animals $[14,18]$. It is unclear whether HIF-1 is induced in adult animals after repeated exposure to acute hypoxia within a short period of time. Our study showed that this might be true.

Reduction of oxygen induced HIF- $1 \alpha$ protein accumulation, and reoxygenation induced a rapid decay of HIF$1 \alpha$ protein. In our model, the mice were exposed repeatedly to hypoxia and normoxia. The HIF- $1 \alpha$ protein level should change in this process. HIF- $1 \alpha$ and HIF-1 DNAbinding activities in the hippocampus were found to be markedly increased after repeated exposure to hypoxia. The changes of the DNA-binding activities of HIF-1 were closely parallel to the HIF- $1 \alpha$ protein level. This result supports our hypothesis that HIF-1 may contribute to the hypoxia tolerance of mice. Our previous findings [3] demonstrated that the energy metabolism might depend on anaerobic glycolysis after preconditioning. HIF-1 regulates the transcriptional activation of target genes such as EPO, VEGF, and glucose transporter (GLUT) and glycolytic enzymes [18-20]. The expression of these genes in response to hypoxia may be a protectively adaptive change. Al- though only one target gene of HIF-1, VEGF, was studied in this context, some other target genes may also be induced during this process for the accumulation of HIF- $1 \alpha$ and the increase of the DNA-binding activities of HIF-1.

HIF- $1 \alpha$ and HIF-1 DNA-binding activities can be detected in the hippocampus of mice under normoxic conditions. HIF- $1 \alpha$ protein detection in the brain has been reported under normoxic conditions [21]. To our knowledge, this work is the first reporting that the transcription factor HIF-1 is constitutively activated in the hippocampus of mice under normoxic condition using an in vivo binding test (ChIP). It has been suggested and supported [21] that the physiological oxygen tension in normal tissue presents a low-level HIF-1 protein to induce target genes to provide the cellular energy requirements. The basal activation of HIF-1 may be necessary to regulate target genes to provide cellular energy and signal in normal brain tissue. This was supported by a mouse model lacking the HIF- $1 \alpha$ gene in neural cells, where the animals exhibited hydrocephalus accompanied by a reduction in neural cells and an impairment of spatial memory [22].

In the present study, the level of VEGF was found to be increased after acute and repeated exposure to hypoxia, and no change was found after a single exposure to hypoxia. In vitro and in vivo studies reported that VEGF plays a neuroprotective role $[23,24]$. The anti-apoptotic signal can be enhanced, and the apoptotic gene may be inhibited through VEGF associated with the PI(3)K/Akt pathway $[25,26]$. Other factors may be involved in this pathway to promote the survival of neurons under hypoxic conditions. Hypoxia preconditioning-induced VEGF may thus protect the brain and promote its tolerance to hypoxia.

The change of HIF- $1 \alpha$ mRNA expression in vivo under hypoxia and hypoxia preconditioning has been studied [14]. A significant induction of HIF- $1 \alpha$ mRNA was found $19 \mathrm{~h}$ after the onset of ischemia [27]. In the present study, the HIF- $1 \alpha$ mRNA levels were found to be increased rapidly and transitorily in the $\mathrm{H} 1$ group and decreased to the basal level after repeated exposure to hypoxia in the $\mathrm{H} 4$ group. This finding is different from the results obtained by Bergeron et al. [14]. This discrepancy could be explained by the difference of the methods for preconditioning. Our model belongs to whole-body hypoxia preconditioning, by which an intrinsic protective potential can be induced within a short period of time [4]. As a key molecule, HIF-1 should play an important role in this process. In our present work, the results of the studies of the HIF$1 \alpha$ protein level and the HIF-1 DNA-binding activities demonstrated that this may be true. The HIF-1 $\alpha$ mRNA contains an internal ribosome entry site that makes effi- 
cient translation equal under normoxic and hypoxic conditions [28]. So the increase of HIF-1 $\alpha$ mRNA means the increase of HIF- $1 \alpha$ protein. The change in group $\mathrm{H} 1 \mathrm{im}-$ plies that the increase in HIF- $1 \alpha$ mRNA as template for protein synthesis is necessary at the beginning of preconditioning. After preconditioning, energy-consuming processes of cells are depressed, and the cells change to hypometabolic states. Both translation and transcription are energy-consuming processes. The transcription of HIF- $1 \alpha$ mRNA is, therefore, depressed, so that the level of HIF- $1 \alpha$ mRNA decreased in group H4. It is likely that the adaptation involves changes in mRNA transcription, but is mainly controlled at the posttranscriptional level.
No direct evidence for the roles of HIF-1 and its target gene in the increase of tolerance to hypoxia is provided in the present study. The changes of HIF-1 and VEGF in the process of acute and repeated hypoxia present an indirect evidence for these possible functions. In conclusion, HIF-1 $\alpha$ activation in autoprogressive hypoxia plays an important role in developing hypoxic preconditioning. Some molecules, such as VEGF, which are HIF-1s downstream and are regulated by it, can be expected to increase in expression. These changes may protect the brain from hypoxic injury.

\section{References}

$>1$ Lu GW, Ding DW, Shi MT: Acute adaptation of mice to hypoxic hypoxia. Biol Signals Recept 1999;8:247-255.

-2 Lu GW, Liu HY: Downregulation of nitric oxide in the brain of mice during their hypoxic preconditioning. J Appl Physiol 2001;91: 1193-1198.

-3 Lu GW, Cui XY, Zhao BM: Alteration of oxygen consumption and energy metabolism during repetitive exposure of mice to hypoxia. Neurochem Res 1999;24:625-628.

-4 Zhang SX, Miller JJ, Gozal D, Wang Y: Wholebody hypoxic preconditioning protects mice against acute hypoxia by improving lung function. J Appl Physiol 2004;96:392-397.

5 Wang GL, Jiang B, Rue EA, Semenza GL: Hypoxia-inducible factor 1 is a basic-helixloop-helix-PAS heterodimer regulated by cellular $\mathrm{O}_{2}$ tension. Proc Natl Acad Sci USA 1995; 92:5510-5514.

-6 Epstein AC, Gleadle JM, McNeill LA, Hewitson KS, O'Rourke J, Mole DR, Mukherji M, Metzen E, Wilson MI, Dhanda A, Tian YM, Masson N, Hamilton DL, Jaakkola P, Barstead $\mathrm{R}$, Hodgkin J, Maxwell PH, Pugh CW, Schofield CJ, Ratcliffe PJ: C. elegans EGL-9 and mammalian homologs define a family of dioxygenases that regulate HIF by prolyl hydroxylation. Cell 2001;107:43-54.

7 Bruick RK, McKnight SL: A conserved family of prolyl-4-hydroxylases that modify HIF. Science 2001;294:1337-1340.

-8 Ivan M, Kondo K, Yang H, Kim W, Valiando J, Ohh M, Salic A, Asara JM, Lane WS, Kaelin WG Jr: HIF $\alpha$ targeted for VHL-mediated destruction by proline hydroxylation: implications for $\mathrm{O}_{2}$ sensing. Science 2001;292:464468.

-9 Jaakkola P, Mole DR, Tian YM, Wilson MI, Gielbert J, Gaskell SJ, von Kriegsheim A, Hebestreit HF, Mukherji M, Schofield CJ, Maxwell PH, Pugh CW, Ratcliffe PJ: Targeting of HIF- $\alpha$ to the von Hippel-Lindau ubiquitylation complex by $\mathrm{O}_{2}$-regulated prolyl hydroxylation. Science 2001;292:468-472.

10 Ohh M, Park CW, Ivan M, Hoffman MA, Kim TY, Huang LE, Pavletich N, Chau V, Kaelin WG Jr: Ubiquitination of hypoxia-inducible factor requires direct binding to the beta-domain of the von Hippel-Lindau protein. Nat Cell Biol 2000;2:423-427.

11 Sakanaka M, Wen TC, Matsuda S, Masuda S, Morishita E, Nagao M, Sasaki R: In vivo evidence that erythropoietin protects neurons from ischemic damage. Proc Natl Acad Sci USA 1998;95:4635-4640.

12 Hayashi T, Abe K, Itoyama Y: Reduction of ischemia damage by application of vascular endothelial growth factor in rat brain after transient ischemia. J Cereb Blood Flow Metab 1998; 18:887-895.

13 Ruscher K, Isaev N, Trendelenburg G, Weih M, Meisel A, Dirnagl U: Induction of hypoxia inducible factor 1 by oxygen glucose deprivation is attenuated by hypoxia preconditioning in rat cultured neurons. Neurosci Lett 1998; 254:117-120.

-14 Bergeron M, Gidday JM, Yu AY, Semenza GL, Ferriero DM, Sharp FR: Role of hypoxiainducible factor-1 in hypoxia-induced ischemic tolerance in neonatal rat brain. Ann Neurol 2000;48:285-296.

15 Semenza GL, Wang GL: A nuclear factor induced by hypoxia via de novo protein synthesis binds to the human erythropoietin gene enhancer at a site required for transcriptional activation. Mol Cell Biol 1992;12:54475454.

16 Dawson VL, Dawson TM: Neuronal ischaemic preconditioning. Trends Pharmacol Sci 2000; 21:423-424.

17 Nandagopal K, Dawson TM, Dawson VL: Critical role for nitric oxide signaling in cardiac and neuronal ischemic preconditioning and tolerance. J Pharmacol Exp Ther 2001; 297:474-478.

18 Jones NM, Bergeron M: Hypoxic precondition induces changes in HIF-1 target genes in neonatal rat brain. J Cereb Blood Flow Metab 2001;21:1105-1114.

19 Bernaudin M, Nedelec AS, Divoux D, MacKenzie ET, Petit E, Schumann-Bard P: Normobaric hypoxia induces tolerance to focal permanent cerebral ischemia in association with an increased expression of hypoxia-inducible factor- 1 and its target genes, erythropoie- tin and VEGF, in adult mouse brain. J Cereb Blood Flow Metab 2002;22:393-403.

-20 Semenza GL, Jiang BH, Leung SW, Passantino R, Concordet JP, Maire P, Giallongo A: Hypoxia response elements in the aldolase A, enolase 1 and lactate dehydrogenase A gene promoters contain essential binding sites for hypoxia-inducible factor 1. J Biol Chem 1996; 271:32529-32537.

21 Stroka DM, Burkhardt T, Desbaillets I, Wenger RH, Neil DA, Bauer C, Gassmann M, Candinas D: HIF-1 is expressed in normoxic tissue and displays an organ-specific regulation under systemic hypoxia. FASEB J 2001;15:2445-2453.

-22 Tomita S, Ueno M, Sakamoto M, Kitahama Y, Ueki M, Maekawa N, Sakamoto H, Gassmann M, Kageyama R, Ueda N, Gonzalez FJ, Takahama Y: Defective brain development in mice lacking the HIF-1 $\alpha$ gene in neural cells. Mol Cell Biol 2003;23:6739-6749.

-23 Jin KL, Mao XO, Greenberg DA: Vascular endothelial growth factor: direct neuroprotective effect in in vitro ischemia. Proc Natl Acad Sci USA 2000;97:10242-10247.

24 Wang Y, Kilic E, Kilic Ü, Weber B, Bassetti C, Marti HH, Hermann DM: VEGF overexpression induces post-ischaemic neuroprotection, but facilitates haemodynamic steal phenomena. Brain 2005; 128:52-63.

25 Romashkova JA, Makarov SS: NF-kappaB is a target of AKT in anti-apoptotic PDGF signalling. Nature 1999;401:86-90.

-26 Jin K, Mao XO, Batteur SP, McEachron E, Leahy A, Greenberg DA: Caspase-3 and the regulation of hypoxic neuronal death by vascular endothelial growth factor. Neuroscience 2001;108:351-358.

-27 Bergeron M, Yu AY, Solway KE, Semenza GL, Sharp FR: Induction of hypoxia-inducible factor-1 (HIF-1) and its target genes following focal ischaemia in rat brain. Eur J Neurosci 1999; 11:4159-4170

28 Gorlach A, Camenisch G, Kvietikova I, Vogt L, Wenger RH, Gassmann M: Efficient translation of mouse hypoxia-inducible factor-1 alpha under normoxic and hypoxic conditions. Biochim Biophys Acta 2000;1493:125-134. 